\title{
Distribution patterns of the crab Ucides cordatus (Brachyura, Ucididae) at different spatial scales in subtropical mangroves of Paranaguá Bay (southern Brazil)
}

\author{
L. Sandrini-Neto $\cdot$ P. C. Lana
}

Received: 28 September 2010 / Revised: 30 March 2011 / Accepted: 7 April 2011 / Published online: 22 April 2011

(C) Springer-Verlag and AWI 2011

\begin{abstract}
Heterogeneity in the distribution of organisms occurs at a range of spatial scales, which may vary from few centimeters to hundreds of kilometers. The exclusion of small-scale variability from routine sampling designs may confound comparisons at larger scales and lead to inconsistent interpretation of data. Despite its ecological and social-economic importance, little is known about the spatial structure of the mangrove crab Ucides cordatus in the southwest Atlantic. Previous studies have commonly compared densities at relatively broad scales, relying on alleged distribution patterns (e.g., mangroves of distinct composition and structure). We have assessed variability patterns of $U$. cordatus in mangroves of Paranaguá Bay at four levels of spatial hierarchy $(10 \mathrm{~s} \mathrm{~km}, \mathrm{~km}, 10 \mathrm{~s} \mathrm{~m}$ and $\mathrm{m})$ using a nested ANOVA and variance components measures. The potential role of sediment parameters, pneumatophore density, and organic matter content in regulating observed patterns was assessed by multiple regression models. Densities of total and non-commercial size crabs varied mostly at $10 \mathrm{~s} \mathrm{~m}$ to $\mathrm{km}$ scales. Densities of commercial size crabs differed at the scales of $10 \mathrm{~s} \mathrm{~m}$ and $10 \mathrm{~s} \mathrm{~km}$. Variance components indicated that small-scale variation was the most important, contributing up to $70 \%$ of the crab density variability. Multiple regression models could not explain the observed variations. Processes driving differences in crab abundance were not related to the measured variables. Small-scale patchy distribution has direct impli-
\end{abstract}

Communicated by Luis Gimenez.

L. Sandrini-Neto $(\bowtie) \cdot$ P. C. Lana

Centro de Estudos do Mar, Universidade Federal do Paraná,

Av. Beira Mar, s/n, Pontal do Paraná 83255-000, Brazil

e-mail: leonardosandrini@gmail.com cations to current management practices of $U$. cordatus. Future studies should consider processes operating at smaller scales, which are responsible for a complex mosaic of patches within previously described patterns.

Keywords Ucides cordatus $\cdot$ Spatial scale . Nested ANOVA · Variance components · Mangrove · Paranaguá Bay

\section{Introduction}

The description patterns of variation of abundance across spatial and temporal scales are essential to understand the factors and processes controlling its distribution (Underwood et al. 2000; Burrows et al. 2009). The scaledependent nature of ecological processes (e.g., dispersion, predation) results in patterns of distribution of organisms varying across a hierarchy of scales, from a few centimeters to hundreds of kilometers (Morrisey et al. 1992; Archambault and Bourget 1996; Hughes et al. 1999; Underwood et al. 2000; Jenkins et al. 2001; Terlizzi et al. 2007).

When the variability at small scales is not estimated, the interpretation of results about patterns of distribution at larger scales may be wrong (Morrisey et al. 1992). Although well documented for the fauna from tidal flats (Ysebaert and Herman 2002), sandy beaches (James and Fairweather 1996), rocky shores (Benedetti-Cecchi et al. 2003; Fraschetti et al. 2005), and sublitoral soft-bottoms (Morrisey et al. 1992; Hewitt et al. 2002), small-scale spatial heterogeneity of mangrove benthic invertebrates has not been well addressed. Faunal distribution patterns from these environments are usually described at relatively large scales, from hundreds of meters to kilometers, and only recently they have been treated from a multiscale perspective 
(Chapman 1998; Chapman and Tolhurst 2007; Piou et al. 2009).

Distribution and density patterns of mangrove benthic species have been frequently related to sediment grain size, pneumatophore density, microphytobenthic biomass, and litter (Chapman and Tolhurst 2004; Piou et al. 2009). However, spatial variation in benthic invertebrates in mangroves is usually found at smaller scales (e.g., meters) than most sediment properties (Chapman and Tolhurst 2004) therefore making difficult their direct correlation. Sampling designs including several spatial scales are crucial to the adequate quantification and representation of mangrove benthic fauna and related environmental variables (Chapman and Tolhurst 2007). The application of hierarchical sampling design is a common way to ensure appropriate replication (Underwood 1997). These designs have become powerful tools when describing spatial variation of soft-bottom benthic assemblages (Morrisey et al. 1992; Ysebaert and Herman 2002; Giménez et al. 2005; Commito et al. 2006), since scales at which variability is higher can be identified through nested allocation of samples (Underwood 1997).

The crab Ucides cordatus (Linnaeus 1763) (Brachyura, Ucididae) is considered a key species of mangrove habitats for its high biomass (Koch and Wolff 2002) and its role in litter dynamics (Schories et al. 2003). Leaf removal by crabs through retention and consumption may reach up to $80 \%$ of the total litter produced (Nordhaus et al. 2006) and contribute to a significant decrease in its exportation to adjacent estuaries. In addition, $U$. cordatus supports a major mangrove fishery along the Brazilian coast (Glaser and Diele 2004; Diele et al. 2005; Legat et al. 2006; Magalhães et al. 2007). Particularly in Northern Brazil, over half of rural coastal households depend on the harvest, processing, transport, or marketing of $U$. cordatus for a main part of their income (Glaser and Diele 2004). Thus, the development of effective management strategies, including the determination of available stocks and sustainable harvesting practices, requires the identification of variability at scales relevant to $U$. cordatus.

Schories et al. (2003) recognized that the density of $U$. cordatus is extremely variable, but did not identify the spatial scales associated with this variability. Piou et al. (2009) showed that galleries are regularly spaced from each other at small scales $(<10 \mathrm{~m})$, but usually aggregated at larger scales (10-100 m). Unfortunately, most available surveys were based on a single spatial scale (Branco 1993; Blankensteyn et al. 1997; Schories et al. 2003; Diele et al. 2005; Wunderlich et al. 2008). Data interpretation from these designs is severely compromised by the lack of proper replication at relevant scales of variability. The identification of processes primarily responsible for variability in the abundance of $U$. cordatus will only be attained when its spatial structure is fully understood. At large scales, crab distribution may be determined by estuarine salinity-energy gradients and hence mangrove typologies; while at smaller scales, biogenic structures, food availability, and intraspecific competition may be major structuring factors (Piou et al. 2009).

In this study, we have quantified $U$. cordatus variability in mangroves of Paranaguá Bay (Paraná, Brazil) at four spatial scales, from meters to $10 \mathrm{~s} \mathrm{~km}$, using a hierarchical sampling design. This is the first time that the spatial distribution of this major mangrove resource has been analyzed in this way. Mangrove stands were sampled along a salinity-energy gradient that operates at the largest spatial scale (10 s km) and hence determines different forest types, from complex and well-structured to monospecific stands (Lana et al. 2001; Lana 2003). Since numerous studies have found large differences in the density of $U$. cordatus among distinct mangrove typologies (e.g., Blankensteyn et al. 1997), we hypothesized that the largest proportion of total variation in crab density would occur at the larger spatial scale $(10 \mathrm{~s} \mathrm{~km})$. At smaller scales, we have assessed the relative contribution of sediment characteristics, organic matter content, and pneumatophore density in regulating the observed distribution patterns.

\section{Methods}

Study area

The study was conducted at Paranaguá Bay $\left(25^{\circ} 30^{\prime} \mathrm{S}\right.$, $48^{\circ} 25^{\prime} \mathrm{W}$ ), a semi-enclosed estuarine system in Paraná State, southern Brazil (Fig. 1). Tides are semi-diurnal with diurnal inequalities and may reach up to $2.7 \mathrm{~m}$ (Lana et al. 2001; Marone et al. 2005). A salinity-energy gradient from freshwater to marine conditions along the east-west and north-south main axes divides the bay into high energy, euhaline (salinity $\approx 30$ ) outer region, a middle polyhaline region, and oligo-mesohaline (salinity $\approx 0-15$ ) low-energy inner sectors (Lana et al. 2001). Local mangroves are usually made up of Rhizophora mangle L., Laguncularia racemosa Gaerth, and Avicennia schaueriana Stapf \& Leechman and display distinct structural heterogeneity, establishing mono-as well as pluri-specific woods.

Sampling methods

The design included four spatial scales of variation: regions $(10 \mathrm{~s} \mathrm{~km})$, locations $(\mathrm{km})$, sites $(10 \mathrm{~s} \mathrm{~m})$, and quadrats $(\mathrm{m})$. Throughout January 2007, three regions (R1 to R3) tens of kilometers apart were sampled across the Paranaguá Bay salinity-energy gradient (Fig. 1). Regions were chosen because of its distinct mangrove typologies determined by vegetation composition and structure, sediment characteristics, 
Fig. 1 Map of Paranaguá Bay showing sampling regions (R1, R2, R3; $10 \mathrm{~s} \mathrm{~km} \mathrm{apart)} \mathrm{and}$ locations within each region (L1, L2, L3; km apart)

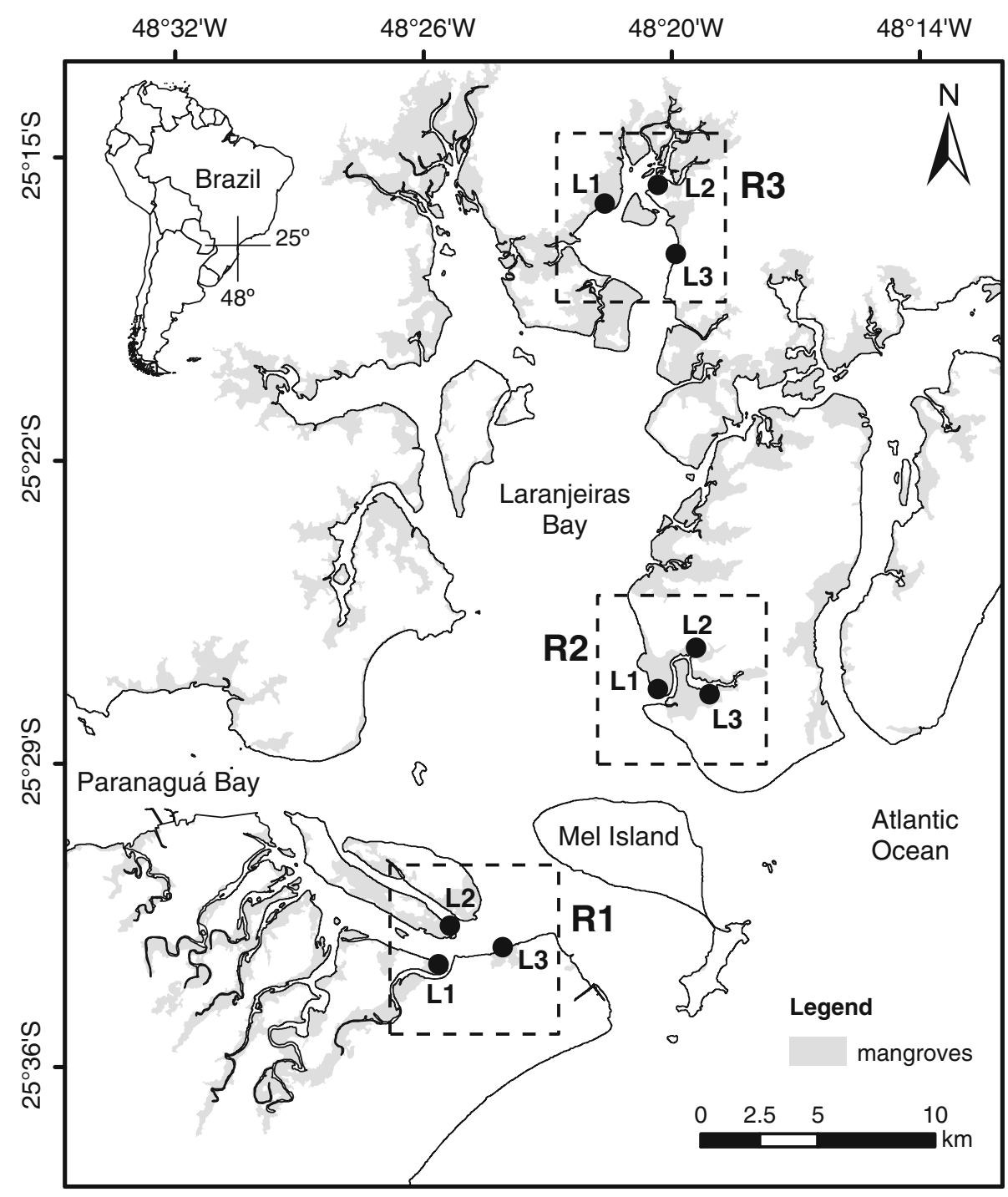

topography, and drainage (Lana 2003). Mangrove stands from R1 and R3 are structurally more complex, with higher tree canopy heights and co-dominance of the three local tree species. Stands from R2, closer to the northern outlet of Paranaguá Bay, are structurally simpler, with lower tree canopy heights and dominance of Laguncularia racemosa. Within each region, three locations $(1.5-3.5 \mathrm{~km}$ apart from each other) were randomly chosen. In each location, three sites of $10 \times 10 \mathrm{~m}$ were randomized, and within these, five quadrats of $2 \times 2 \mathrm{~m}$ were sampled.

Within each quadrat, burrow sizes were measured with a caliper $(0.05 \mathrm{~mm}$ precision). U. cordatus burrows are easily recognized in the field and broadly used as a proxy of crab density and size (Piou et al. 2009). Only active galleries, identified by the presence of fluid mud, feces, and/or animal traces close to the opening, were considered. Closed burrows were not counted due to little occurrence during the sampling period (Wunderlich et al. 2008). Openings of $60 \mathrm{~mm}$ or more were attributed to commercial size crabs (Blankensteyn et al. 1997).
Sediment samples were collected with a PVC corer $(10 \mathrm{~cm}$ diameter $\times 10 \mathrm{~cm}$ deep $)$ in each site and frozen until analysis. Sediment analysis was conducted by pipetting and sieving and granulometric parameters (i.e., sediment grain size in phi, sorting and clay percentage) obtained using SysGran software, version 3.0 (Camargo 2006). Organic matter content was determined by differences between initial and final weights after burning $5 \mathrm{~g}$ of sediment in a muffle furnace for $1 \mathrm{~h}$ at $550^{\circ} \mathrm{C}$. Pneumatophores were systematically counted in each quadrat. Dominant mangrove species were identified, and mean tree height was estimated in each site. Structure and composition of mangroves could only be assessed at larger scales than those used to estimate crab density, because the sampling units usually used to estimate mangrove stands' parameters are necessarily much larger. This description attempted to provide additional semi-quantitative or qualitative information on the structural heterogeneity of the sampled mangroves. 
Data analysis

Total (non-commercial plus commercial size crabs), noncommercial (burrow size $<60 \mathrm{~mm}$ ), and commercial size (burrow size $\geq 60 \mathrm{~mm}$ ) $U$. cordatus densities were analyzed separately using a pure random effects-nested ANOVA. The objective was to identify the scales that contributed most to the variation in crabs' density. Both statistical significance and variance components (magnitude of effect) were estimated. The latter were calculated using the residual maximum likelihood (REML) method, which is insensitive to negative estimates. Thus, the "pool-the-minimum-violator" procedure, recommended by Fletcher and Underwood (2002) for this particular case, was not necessary.

Normality and homogeneity of variances were, respectively, assessed by Kolmogorov-Smirnov and Bartlett tests. Data transformation of total and non-commercial size crabs densities was not necessary. Density of commercial size crabs was transformed to square root attempting to meet the homogeneity of variances assumption. Normality for this data was not possible to accomplish even when transformed. Even though this violates the assumptions of ANOVA, it does not represent a major problem to data processing and interpretation, which remains consistent notwithstanding the lack of normality (Underwood 1997).

Relationships between environmental factors and burrow density were evaluated at the scale of sites. Multiple regression was used, with burrow density as response variable and sediment grain size, sorting, clay percentage, organic matter content, and density of pneumatophores as predictor variables. Homogeneity of variances, non-collinearity among variables, and normality of errors assumptions were checked and no transformation was necessary. A stepwise forward procedure was used to determine the best model. Means from the five quadrats were taken to determine crab density and pneumatophores density, since only one sediment sample per site was available.

All statistical analysis and graphs were generated using $\mathrm{R}$ programming language ( $\mathrm{R}$ Development Core Team 2009) combined with nlme (Pinheiro et al. 2009) and sciplot (Morales 2009) packages.

\section{Results}

Mangroves from Region 1 were mostly made up of Rhizophora mangle and Avicennia schaueriana, while Laguncularia racemosa occurred more often only at two sites. Mean height varied from 5 to $8 \mathrm{~m}$ at sites dominated by A. schaueriana and $R$. mangle and remained at $3 \mathrm{~m}$ at those dominated by $L$. racemosa. Mangroves from Region 2 showed a rather homogenous structure, consisting of L. racemosa mono-specific forests of ca. $3.5 \mathrm{~m}$ high. Region 3 mangroves were structurally complex, with plurispecific stands and mean height ranging from 6 to $10 \mathrm{~m}$.

About $60 \%$ of the total counted burrows belonged to non-commercial size crabs, which presented a higher density $\left(1.35 \pm 0.96\right.$ burrows $\left.\mathrm{m}^{-2}\right)$ than commercial size crabs $\left(0.86 \pm 0.62\right.$ burrows $\left.\mathrm{m}^{-2}\right)$. Total and non-commercial crabs' densities varied significantly $(P<0.05)$ among locations and sites, but were similar among regions (Table 1; Figs. 2a-c, 3a-c). Differences in commercial size density were marginally significant $(0.05<P<0.06)$ among regions and sites, with lower densities at Region 2 (Table 1; Fig. 4a-c).

Generally, density patterns were strongly dominated by small-scale variability (i.e., among replicated quadrats few meters apart within each site) (Fig. 5). The large scale (regions tens of kilometers apart from each other) did not contribute significantly to the variability of total and noncommercial crab densities. However, the regions accounted for about $20 \%$ of commercial size crabs variance (Fig. 5). High variance components calculated for the quadrat level (i.e., the residual) indicated that total as well as noncommercial and commercial size crab abundance were patchy at the smaller spatial scale.

Stepwise forward multiple regressions selected models including a single independent variable and rather limited explanation of the total and non-commercial size crabs distribution patterns (Table 2). Mean sediment grain size (phi) accounted, respectively, for 16 and $15 \%$ of total and non-commercial variability. Despite the low coefficient of determination, the negative relation between these variables suggests a decrease in total and non-commercial $U$. cordatus abundance in areas with finer sediments. No variables

Table 1 Nested analysis of variance for spatial variation in mean number of crab burrows at different spatial scales

\begin{tabular}{|c|c|c|c|c|c|c|c|c|c|c|}
\hline \multirow[t]{2}{*}{ Source } & \multirow[t]{2}{*}{$d f$} & \multicolumn{3}{|c|}{ Total crab burrows } & \multicolumn{3}{|c|}{ Crab burrows $<60 \mathrm{~mm}$} & \multicolumn{3}{|c|}{ Crab burrows $\geq 60 \mathrm{~mm}$} \\
\hline & & MS & $F$ & $P$ & MS & $F$ & $P$ & MS & $F$ & $P$ \\
\hline Region & 2 & 7.050 & 1.366 & 0.324 & 3.629 & 0.954 & 0.437 & 1.897 & 4.826 & 0.056 \\
\hline Location $(R)$ & 6 & 5.162 & 2.741 & 0.045 & 3.804 & 3.243 & 0.024 & 0.393 & 2.146 & 0.098 \\
\hline Site $(\mathrm{L}(R))$ & 18 & 1.883 & 2.130 & 0.009 & 1.173 & 1.746 & 0.042 & 0.183 & 1.691 & 0.052 \\
\hline Residual & 108 & 0.884 & & & 0.672 & & & 0.108 & & \\
\hline
\end{tabular}


Fig. 2 Mean (SE, $n=5)$ number of Ucides cordatus burrows among a regions, b locations, and $\mathbf{c}$ sites
Fig. 3 Mean (SE, $n=5)$ number of non-commercial size Ucides cordatus burrows among a regions, $\mathbf{b}$ locations, and c sites

\section{Total crab burrows}

(a)

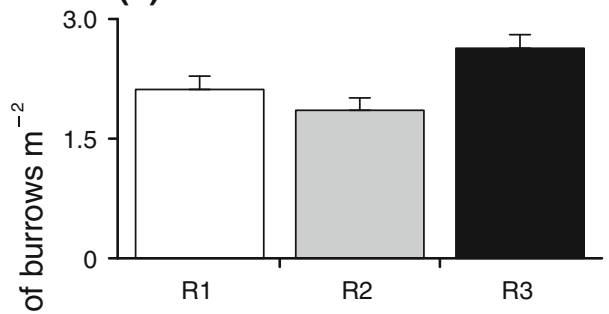

(c) (b)

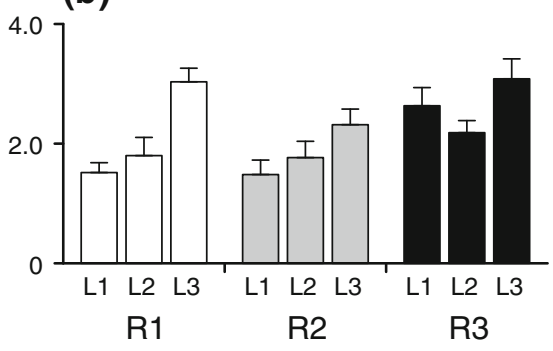

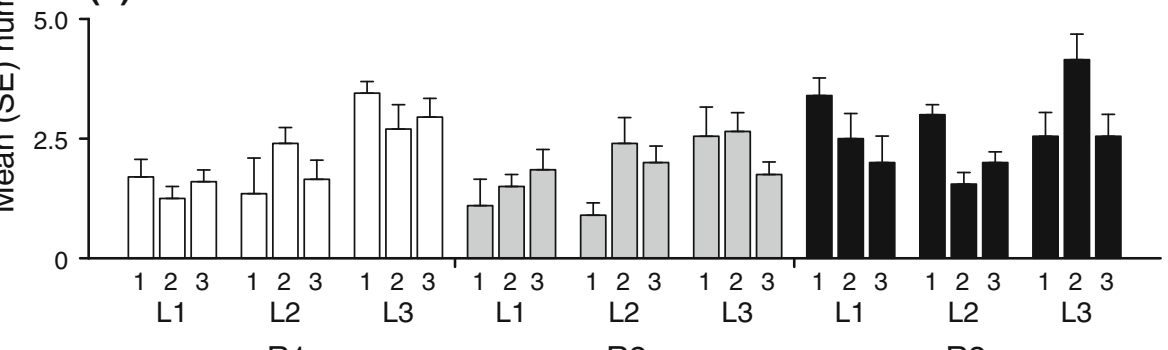

R1

$\mathrm{R} 2$

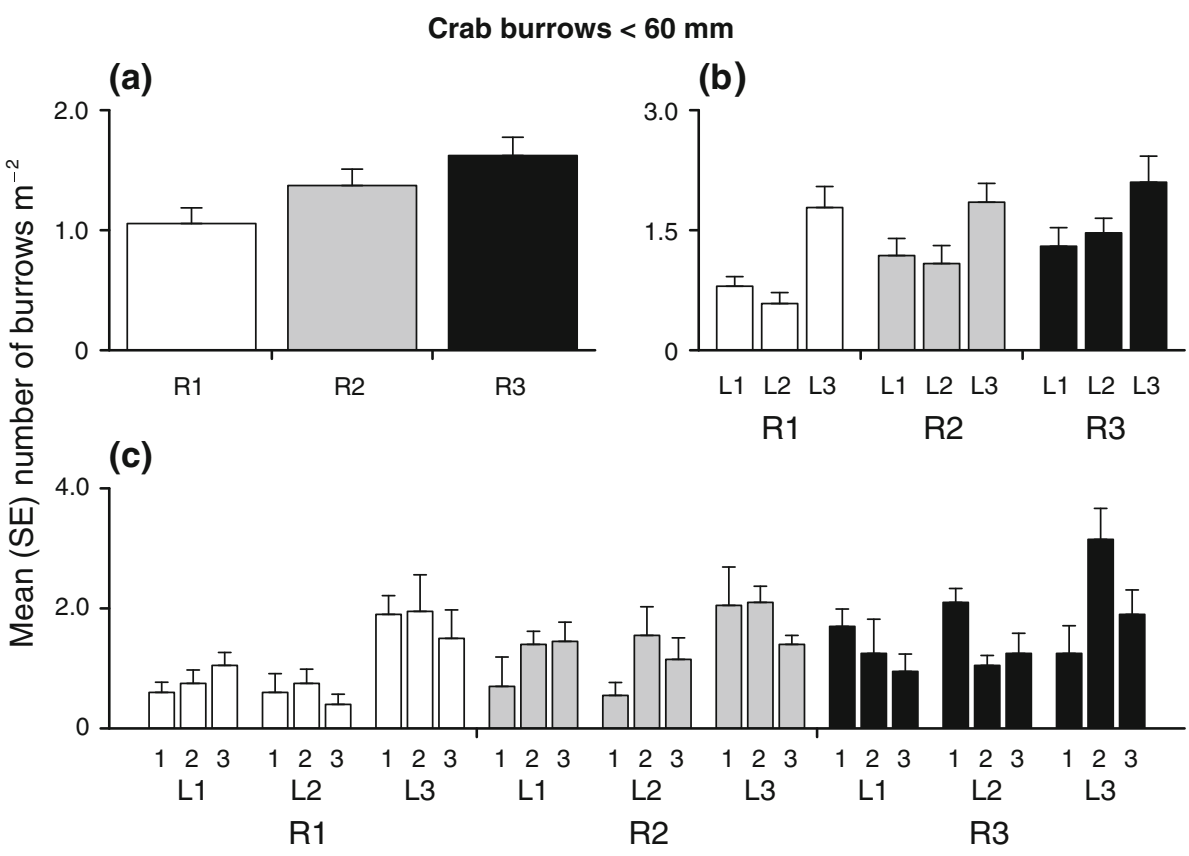

were selected that would explain the observed variability of commercial size crabs (Table 2).

\section{Discussion}

We rejected the hypothesis that the scale of tens of kilometers, which is responsible for the major variation in the structure of mangrove stands, accounts for most of the variation in crab density. Distribution of $U$. cordatus was patchy at the smallest spatial scale with the larger proportion of total variance occurring among replicates. Thus, densities differed significantly among quadrats just a few meters apart and these differences were larger than those measured at larger scales. This small-scale variability, particularly in meters, is a well-known pattern in most benthic habitats (Morrisey et al. 1992; Underwood and Chapman 1996; Olabarria and Chapman 2001; Ysebaert and Herman 2002; Commito et al. 2006) including mangroves (Chapman 1998; Chapman and Tolhurst 2007) and stresses the need for the quantification of abundance patterns at a hierarchy of spatial scales. 
Fig. 4 Mean (SE, $n=5)$ number of commercial size Ucides cordatus burrows among a regions, b locations, and c sites
Crab burrows $>60 \mathrm{~mm}$ (a)

(c)

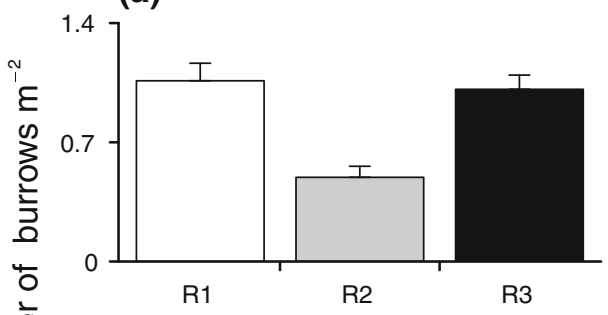

(b)

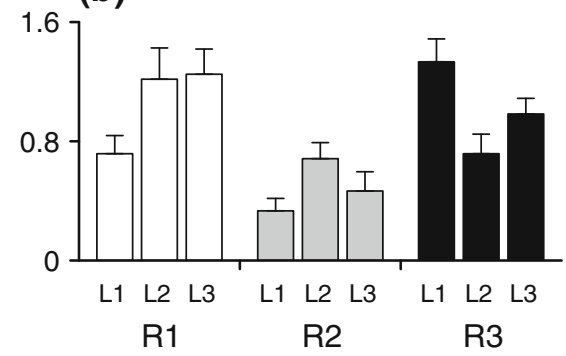

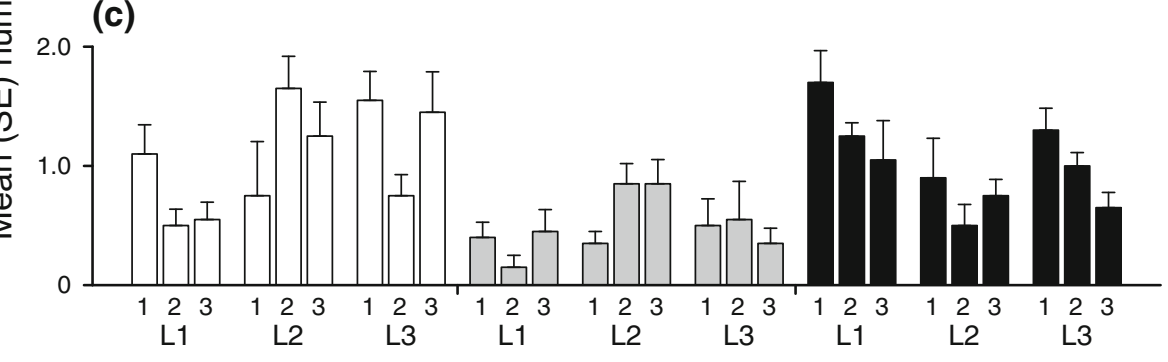

R1

$\mathrm{R} 2$

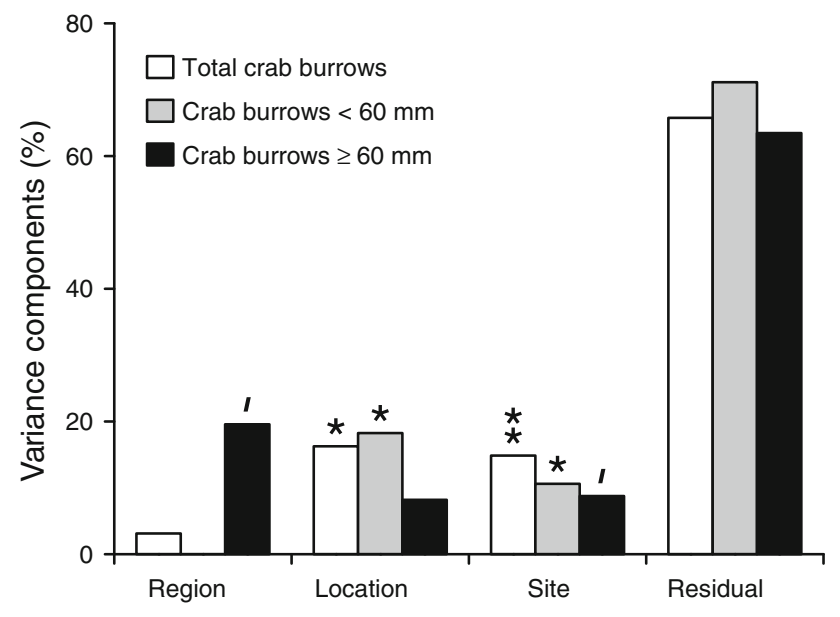

Fig. 5 Percent variance components for Ucides cordatus densities among regions, locations, sites, and residual (i.e., quadrats). 'Marginally significant difference $(0.05<P<0.06) ; * P<0.05 ; * * P<0.01$

Such large small-scale variation should not be treated simply as uninteresting "noise" (Carroll 2003) but as relevant ecological information. Although apparently chaotic, small-scale patchiness results from specific ecological processes operating at very fine scales. These may be related to the patchy distribution of microhabitats, small-scale changes in environmental conditions, behavior and competition. For example, habitat choice and recruitment of $U$. cordatus megalopae are strongly induced by environmental cues associated with the presence of conspecific crabs and muddy sediments (Diele and Simith 2007), which is likely to be more important in regulating patterns of distribution at small scales. Other small-scale processes, such as intraspecific competition, may explain the differences in the
Table 2 Multiple regression analysis between burrow densities and environmental variables (mean grain size, sorting, clay percentage, organic matter content, and pneumatophore density)

\begin{tabular}{lllll}
\hline Dependent variable & Effect & $\beta$ & $R^{2}$ & $P$ \\
\hline Total crab burrows & Mean grain size & -0.404 & 0.16 & 0.037 \\
Crab burrows $<60 \mathrm{~mm}$ & Mean grain size & -0.383 & 0.15 & 0.048 \\
Crab burrows $\geq 60 \mathrm{~mm}$ & None & & &
\end{tabular}

The only variable selected in the stepwise forward procedure was mean grain size. $\beta$ partial correlation coefficient; $R^{2}$ coefficient of determination

spatial patterns of non-commercial and commercial size crabs, since large crabs apparently exclude smaller ones from preferred habitats (Piou et al. 2009).

It is very unlikely that large-scale processes, such as wave-action or salinity gradients, regulate the distribution of fauna at smaller scales. Overall distribution of $U$. cordatus has been variously attributed to abiotic factors, such as sediment texture and flood rates, or biological factors, such as mangrove composition/structure and pneumatophore density (Blankensteyn et al. 1997; Schories et al. 2003; Nordhaus et al. 2009; Piou et al. 2009). However, most of these factors cannot explain spatial variations in burrow densities at the scales of sites and replicates. The size of the sampling units needed to adequately sample such variables is much larger than the scales mostly responsible for variation in crabs' density. Mangrove composition and structure are mostly assessed at relatively large plots (typically $10 \times 10 \mathrm{~m}$ or larger). The heterogeneity in the distribution and density of $U$. cordatus is greater within than between such putatively sources of variation. This implies that density comparisons among mangroves of different typologies are potentially confounded. 
The amount of total variability in crab density explained by multiple regressions was low. Moreover, only one variable (i.e., mean sediment grain size) was selected in the stepwise forward procedure. The relationships between mangrove benthic fauna and sediment properties are usually weak and variable among different habitats and may display extremely complex patterns at scales ranging from a few meters to several kilometers (Chapman and Tolhurst 2007). This is a possible response to a number of processes operating at these scales, including sediment reworking by the fauna itself. Mangrove microtopography and sediment stability may be modified by crabs that bring fine and cohesive particles to the surface (Botto and Iribarne 2000). Multiple regression models showed the complexity of such interactions and the weak relation between sediment variables and crab density. The lack of paired measures of crab burrows and sediment also contributed to decrease the likelihood of significant correlations, even when considering that benthic animals in mangroves are more variable at the scale of meters while most sediment properties (e.g., grain size) differ at slightly larger scales (Chapman and Tolhurst 2004; Chapman and Tolhurst 2007).

The results of our multiscale approach have relevant implications for the current management procedures of Ucides cordatus. Crab densities are often calculated from unbalanced and poorly replicated designs to estimate regional standing stocks. Scale confounding may turn specifically relevant when densities estimated from singlescale surveys are extrapolated to other relevant scales (Morrisey et al. 1992). Most available studies in tropical and subtropical areas have extrapolated densities of $U$. cordatus measured at a single (usually large) spatial scale to whole mangrove areas (Branco 1993; Blankensteyn et al. 1997). An example of such confounding is shown by the results for total density of $U$. cordatus, in which significant variation was found at scales of sites $(10 \mathrm{~s} \mathrm{~m})$ and locations $(\mathrm{km})$, but not among regions $(10 \mathrm{~s} \mathrm{~km})$. Any attempt to compare regions based on punctual or single-site samplings would be confounded by variation at these scales within each region. Estimates of densities at the scale of regions would have been extremely overestimated or underestimated, and spurious differences would have been found among regions, as previously shown by Morrisey et al. (1992) for other benthic species. This is particularly pertinent when defining a preferred habitat type or quantifying crabs' stocks at a regional level for fishery management purposes.

Acknowledgments We thank Daiane Faller, Fernanda Souza, Linus Menezes, Marcela Lang, Marcelo Muller, Ricardo Haponiuk, Tiago Mafra, and Wagner Pieper for their assistance in the fieldwork. We also thank two anonymous reviewers for helpful comments on our manuscript.

\section{References}

Archambault P, Bourget E (1996) Scales of coastal heterogeneity and benthic intertidal species richness, diversity and abundance. Mar Ecol Prog Ser 136:111-121

Benedetti-Cecchi L, Maggi E, Bertocci I, Vaselli S, Micheli F, Osio GC, Cinelli F (2003) Variation in rocky shore assemblages in the northwestern Mediterranean: contrasts between islands and the mainland. J Exp Mar Biol Ecol 293:193-215

Blankensteyn A, Cunha D, Freire AS (1997) Distribuição, estoques pesqueiros e conteúdo protéico do caranguejo do mangue Ucides cordatus (L. 1763) (Brachyura: Ocypodidae) nos manguezais da Baía das Laranjeiras e adjacências, Paraná, Brasil. Arq Biol Tecnol 40:331-349

Botto F, Iribarne O (2000) Contrasting effects of two burrowing crabs (Chasmagnathus granulata and Uca uruguayensis) on sediment composition and transport in estuarine environments. Estuar Coast Shelf Sci 51:141-151

Branco JO (1993) Aspectos bioecológicos do caranguejo Ucides cordatus (Linnaeus, 1763) (Crustacea, Decapoda) do manguezal do Itacorubi, Santa Catarina, BR. Arq Biol Tecnol 36:133-148

Burrows MT, Harvey R, Robb L, Poloczanska ES, Mieszkowska N, Moore P, Leaper R, Hawkins SJ, Benedetti-Cecchi L (2009) Spatial scales of variance in abundance of intertidal species: effects of region, dispersal mode, and trophic level. Ecology 90:1242-1254

Camargo MG (2006) SysGran: um sistema de código aberto para análises granulométricas do sedimento. Rev Bras Geociência $36: 345-352$

Carroll RJ (2003) Variances are not always nuisance parameters. Biometrics 59:211-220

Chapman MG (1998) Relationships between spatial patterns of benthic assemblages in a mangrove forest using different levels of taxonomic resolution. Mar Ecol Prog Ser 162:71-78

Chapman MG, Tolhurst TJ (2004) The relationship between invertebrate assemblages and bio-dependant properties of sediment in urbanized temperate mangrove forests. J Exp Mar Biol Ecol 304:51-73

Chapman MG, Tolhurst TJ (2007) Relationships between benthic macrofauna and biogeochemical properties of sediments at different spatial scales and among different habitats in mangrove forests. J Exp Mar Biol Ecol 343:96-109

Commito JA, Dow WE, Grupe BM (2006) Hierarchical spatial structure in soft-bottom mussel beds. J Exp Mar Biol Ecol 330:27-37

Diele K, Simith DJB (2007) Effects of substrata and conspecific odour on the metamorphosis of mangrove crab megalopae, Ucides cordatus (Ocypodidae). J Exp Mar Biol Ecol 348:174-182

Diele K, Koch V, Saint-Paul U (2005) Population structure, catch composition and CPUE of the artisanally harvested mangrove crab Ucides cordatus (Ocypodidae) in the Caeté estuary, North Brazil: indications for overfishing? Aquat Living Resour 18:169-178

Fletcher DJ, Underwood AJ (2002) How to cope with negative estimates of components of variance in ecological field studies. J Exp Mar Biol Ecol 273:89-95

Fraschetti S, Terlizzi A, Benedetti-Cecchi L (2005) Patterns of distribution of marine assemblages from rocky shores: evidence of relevant scales of variation. Mar Ecol Prog Ser 296:13-29

Giménez L, Borthagaray AI, Rodríguez M, Brazeiro A, Dimitriadis C (2005) Scale-dependent patterns of macrofaunal distribution in soft-sediment intertidal habitats along a large-scale estuarine gradient. Helgol Mar Res 59:224-236

Glaser M, Diele K (2004) Asymmetric outcomes: assessing central aspects of the biological, economic and social sustainability of a mangrove crab fishery, Ucides cordatus (Ocypodidae), in North Brazil. Ecol Econ 49:361-373 
Hewitt JE, Thrush SF, Legendre P, Cummings VJ, Norkko A (2002) Integrating heterogeneity across spatial scales: interactions between Atrina zelandica and benthic macrofauna. Mar Ecol Prog Ser 239:115-128

Hughes TP, Baird AH, Dinsdale EA, Moltschaniwskyj NA, Pratchett MS, Tanner JE, Willis BL (1999) Patterns of recruitment and abundance of corals along the Great Barrier Reef. Nature 397:5963

James RJ, Fairweather PG (1996) Spatial variation of intertidal macrofauna on a sandy ocean beach in Australia. Est Coast Shelf Sci 43:81-107

Jenkins SR, Åberg P, Cervin G, Coleman RA, Delany J, Hawkins SJ, Hyder K, Myers AA, Paula J, Power AM, Range P, Hartnoll RG (2001) Population dynamics of the intertidal barnacle Semibalanus balanoides at three European locations: spatial scales of variability. Mar Ecol Prog Ser 217:207-217

Koch V, Wolff M (2002) Energy budget and ecological role of mangrove epibenthos in the Caeté estuary, North Brazil. Mar Ecol Prog Ser 228:119-130

Lana PC (2003) Manguezais, legislação e gestão de áreas costeiras: o caso da Baía de Paranaguá. In: Vieira PF (ed) Conservação da diversidade biológica e cultural em zonas costeiras: enfoques e experiências na América Latina e no Caribe. Aped, Florianópolis, pp 313-331

Lana PC, Marone E, Lopes RM, Machado EC (2001) The subtropical estuarine complex of Paranaguá Bay, Brazil. In: Seeliger U, Kjerfve B (eds) Coastal marine ecosystems of Latin America. Springer, Berlin, pp 131-145

Legat JFA, Mota RI, Puchnick A, Bittencourt C, Santana WS (2006) Considerations about Ucides cordatus cordatus fishing in the Parnaiba River Delta region, Brazil. J Coast Res 3:1281-1283

Magalhães A, Costa RM, Silva R, Pereira LCC (2007) The role of women in the mangrove crab (Ucides cordatus, Ocypodidae) production process in North Brazil (Amazon region, Pará). Ecol Econ 61:559-565

Marone E, Machado EC, Lopes RM, Silva ET (2005) Land-ocean fluxes in the Paranaguá Bay estuarine system, southern Brazil. Braz J Oceanogr 53:169-181

Morales M (2009) Sciplot: scientific graphing functions for factorial designs. R package version 1.0-6. http://www.R-project.org

Morrisey DJ, Howitt I, Underwood AJ, Stark JS (1992) Spatial variation in soft-sediment benthos. Mar Ecol Prog Ser 81:197-204
Nordhaus I, Wolff M, Diele K (2006) Litter processing and population food intake of the mangrove crab Ucides cordatus in a high intertidal forest in northern Brazil. Est Coast Shelf Sci 67:239-250

Nordhaus I, Diele K, Wolff M (2009) Activity patterns, feeding and burrowing behaviour of the crab Ucides cordatus (Ucididae) in a high intertidal mangrove forest in North Brazil. J Exp Mar Biol Ecol 374:104-112

Olabarria C, Chapman MG (2001) Comparison of patterns of spatial variation of microgastropods between two contrasting intertidal habitats. Mar Ecol Prog Ser 220:201-211

Pinheiro J, Bates D, DebRoy S, Sarkar D (2009) nlme: linear and nonlinear mixed effects models. R package version 3.1-96. http:// www.R-project.org

Piou C, Berger U, Feller IC (2009) Spatial structure of a leaf-removing crab population in a mangrove of North-Brazil. Wetl Ecol Manag 17:93-106

Schories D, Barletta-Bergan A, Barletta M, Krumme U, Mehlig U, Rademaker V (2003) The keystone role of leaf-removing crabs in mangrove forests of North Brazil. Wetl Ecol Manag 11:243-255

R Development Core Team (2009) R: A language and environment for statistical computing. R Foundation for Statistical Computing, Vienna, Austria. ISBN 3-900051-07-0. http://www.R-project.org

Terlizzi A, Anderson MJ, Fraschetti S, Benedetti-Cecchi L (2007) Scales of spatial variation in Mediterranean subtidal sessile assemblages at different depths. Mar Ecol Prog Ser 332:25-39

Underwood AJ (1997) Experiments in ecology: their logical design and interpretation using analysis of variance. Cambridge University Press, Cambridge

Underwood AJ, Chapman MG (1996) Scales of spatial patterns of distribution of intertidal invertebrates. Oecologia 107:212-224

Underwood AJ, Chapman MG, Connell SD (2000) Observations in ecology: you can't make progress on process without understanding the patterns. J Exp Mar Biol Ecol 250:97-115

Wunderlich AC, Pinheiro MAA, Rodrigues AMT (2008) Biologia do caranguejo-uçá, Ucides cordatus (Crustacea: Decapoda: Brachyura), na Baía da Babitonga, Santa Catarina, Brasil. Rev Bras Zool $25: 188-198$

Ysebaert T, Herman PMJ (2002) Spatial and temporal variation in benthic macrofauna and relationships with environmental variables in an estuarine, intertidal soft-sediment environment. Mar Ecol Prog Ser 244:105-124 